\title{
MIEJSCE PAMIĘCI - PAMIĘĆ MIEJSCA, DEFINIOWANIE I ZASADY OCHRONY W DOKUMENTACH PLANISTYCZNYCH ŁODZI
}

Sites of Memory - memory of the site, defining and rules of protection in Lodz planning documents Maria Dankowska*

SUMMARY: Some places hold our collective memory in a particular way, they are a material carrier of our history and identity. One of the possibilities of the protection and exposure of such places are the arrangements of planning documents. They reveal not only memorial sites of national rank but also others. The categorization of memory places is also important from the point of view of their protection. In Lodz, the currently developed study document highlights: 1) places of battles and martyrdom, 2) graves and war graves, 3) monuments and stone obelisks, 4) cemeteries (including forgotten cemeteries),5) demolished synagogues, 6) memorial plaques.
Sites of Memory are a difficult, multi-threaded subject, often affecting delicate issues, such as human feelings, memory, these are also places with which they bind painful and sad memories. All the more, we need to point out the need for great care and diligence at every stage of their recognition, defining or formulating the principles of protection or allowing for any transformation. Passing the memory of the place through the preservation of Sites of Memory is a huge collective responsibility and a challenge.

KEYWORDS: Sites of Memory, cultural heritage, identity

\section{Poszukiwanie tożsamości poprzez pamięć miejsca}

W Wojewódzkim Programie Opieki nad Zabytkami w Województwie Łódzkim na stronie tytułowej przywołano znaczącą sentencję Owidiusza: „Czas mija, pomniki pozostają”. Jednak nie zawsze udaje się zachować pomniki, obiekty historyczne, lub inne charakterystyczne materialne przejawy działalności człowieka. Pozostaje wówczas jedynie pamięć miejsca, która trwa wówczas, gdy trwają jej powiernicy, gdy jest przekazywana dalej, kolejnym powiernikom, przez przekaz ustny, lub w formie spisanej opowieści, książki, legendy, pieśni itp., lub też gdy zostaje ona upamiętniona, utrwalona np. w postaci pomnika, tablicy, drzewa, głazu lub w innej, materialnej postaci. Symboliczne nośniki pamięci stają się zatem materialnym zastępstwem, uwidocznieniem pamięci niematerialnej. Znakiem przestrzennym, aby nie zaginęła przez przypadek pamięć o tym, o czym chcemy i powinniśmy pamiętać. Tak rozumiane symboliczne miejsca pamięci mają także wymiar edukacyjny. Rozbudzają pytania i ciekawość kolejnych pokoleń, skłaniają do refleksji i zadumy, do sięgnięcia do przeszłości i „korzeni”. W miejscach pamięci dziedzictwo materialne jest integralnie związane z dziedzictwem niematerialnym, z pamięcią miejsca.

* Maria Dankowska, Lodz University of Technology https://orcid.org/0000-0003-3366-009

1 Wojewódzki Program Opieki nad Zabytkami w Województwie Łódzkim na lata 2016-2019, https://www.lodzkie. pl/kultura/ochrona-zabytkow/program-opieki-nad-zabytkami [dostęp 2018-02-15]. 
Otaczający nas krajobraz, znajdująca się w nim zabudowa (materialne dziedzictwo), konkretne miejsce w przestrzeni jest często nośnikiem pamięci, sceną w której dawniej miały miejsce istotne wydarzenia, lub też związane są z obecnością ważnych postaci. Zwykle fakt taki upamiętniamy, przywołujemy za pomocą nośników materialnych, czasem jednak pamięć ta umyka, nie utrwalona przypadkowo, lub celowo. Zatem czas mija, pamięć zaciera się, i tylko niektórzy, świadomi, pamiętający widzą i rozumieją historię, ducha miejsca w którym się znajdują.

„Tożsamość przynależy wyłącznie człowiekowi jako immanentna cecha świadomości, umożliwiająca nam "nawigowanie” w wieloaspektowej rzeczywistości oraz istnienie (trwanie, przetrwanie) w przestrzeni fizycznej, społecznej i myślowej." Tożsamość tę przyrównują Affelt i Szlaga do więzi emocjonalnej z otoczeniem, krajobrazem i znajdującymi się w nim artefaktami, jaka zadzierzga się „na skutek długotrwałego bytowania (zasiedzenia) człowieka”". Dalej wskazują oni, jak ważne jest zachowanie autentyczności, integralności i unikatowości, aby zasoby kulturowe miejsca zachowały „swoją moc oddziaływania estetycznego" i aby mogły nadal „w przyszłości pełnić rolę kulturotwórczą. ${ }^{3 "}$ Równie ważne jest aby w procesach rozwoju miasta, jego rewitalizacji lub restrukturyzacji pamiętać o zachowaniu zarówno substancji jak $i$ istoty miejsc, co dopiero łącznie stanowić może nośnik naszej zbiorowej oraz indywidualnej pamięci i tożsamości. Zatem w rozpoznawaniu wartości miejsca, istotne jest spojrzenie szerokie, wielodyscyplinarne, uwzględniające zarówno dziedzictwo materialne, jak i niematerialny przekaz jaki w sobie zawiera. Na potrzebę takiego podejścia do miast zwraca uwagę profesor Kłosek-Kozłowska pisząc, że dopiero „naukowe rozpoznanie wartości dziedzictwa miast wyrażające sens i znaczenie miejsc jest podejściem strukturalnym"4. Podejście takie należy także zastosować w rozpoznaniu poszczególnych części miasta, jego zespołów budowlanych i krajobrazowych, a w szczególności w odniesieniu do miejsc pamięci.

\section{Pamięć zbiorowa i pamięć indywidualna}

Niektóre miejsca przypominają nam o wydarzeniach z naszego życia, przywołują rodzinne wspomnienia, czas dzieciństwa, chwile podniosłe, niezapomniane. Niezależnie od wyglądu tych miejsc ich piękno lub brzydotę będziemy uznawać subiektywnie poprzez pryzmat naszych przeżyć i naszych wspomnień. Miejsca te są ważne dla nas, indywidualnie, czasem nawet chcemy by były one naszą tajemnicą, sekretem.

Zupełnie inna percepcja oraz inna ranga przypisana jest do miejsc pamięci zbiorowej,

2 W. Affelt, M. Szalaga, Stocznia Gdańska - rewitalizacja pamięci czy obiektu?” [w:] Prorevita 2010, Zakres i granice ingerencji konserwatorskiej $w$ adaptacji obiektów i zespołów poprzemysłowych, red. A. KępczyńskaWalczak, Łódź, s.80.

3 Ibidem, s. 98.

4 D. Kłosek-Kozłowska, Historyczny Krajobraz Miejski (Historic Urban Landscape - HUL) - uwagi metodologiczne do propozycji międzynarodowego standardu ochrony [w:] Prorevita 2010, Zakres i granice ingerencji konserwatorskiej w adaptacji obiektów i zespołów poprzemysłowych, red. A. Kępczyńska-Walczak, Łódź, s. 303. 


\section{Miejsce pamięci- pamięc miejsca, definiowanie i zasady ochrony [...]}

lokalnej, regionalnej, narodowej, europejskiej czy światowej. Miejsca takie stają się naszym wspólnym dziedzictwem, a ich zachowanie leży w naszym wspólnym interesie. Miejsca pamięci i pamięć o nich jest przekazywana z pokolenia na pokolenie. Jednak, na co zwraca uwagę Kowalski, jest to proces, którego nie można utożsamiać z prawdą o przeszłości. Miejsca pamięci, będące szczególnym rodzajem dziedzictwa, są miejscami wskazanymi przez współczesnych, wybranymi spośród innych miejsc z przeszłości w celu wykreowania obecnej rzeczywistości ${ }^{5}$. Transmisja dziedzictwa może się dokonywać z pominięciem prawdy i fałszu (...). Inaczej mówiąc dziedzictwo niekoniecznie odwołuje się do wiedzy lub prawdy, ale jego istotą jest raczej pewien rodzaj osądu i płynąca z niego decyzja oraz wymiana opinii (...)”6. Często to dopiero „kontekst społeczny dostarcza ram, w których możliwe jest przypominanie, zapominanie i pamiętanie" Bowiem jako współczesne pokolenia, będące „dziedzicami” pamięci, nie tylko możemy zaakceptować spuściznę, dziedzictwo, które otrzymujemy, ale możemy je także odrzucić.

Pamięć zbiorowa, to również poszukiwanie tożsamości, tworzenie więzi z przeszłością i historią. Stąd w obecnych dyskusjach i rozważaniach „miejsce pamięci” rozumiane jest przede wszystkim jako zinstytucjonalizowana przestrzeń, miejsce, obiekt (często nawet wskazany zarządzeniem, dokumentem powołującym, konstytuującym). Tak rozumiane miejsca pamięci stają się nie tylko nośnikiem zbiorowej pamięci, „lecz także narzędziem i celem władzy”. Taką zinstytucjonalizowaną rangę przybierają m.in. zbiory muzealne, biblioteczne czy archiwalne, a także wszelkie miejsca oznakowane jako dziedzictwo przeszłości (np. zabytki, obiekty Dziedzictwa Europejskiego).

\section{Materialny nośnik wartości niematerialnej, różnorodność formy}

„Nośniki pamięci są elementem kultury historycznej - szerszego tła, w którym funkcjonują" można je podzielić na intencjonalne oraz mimowolne, oraz wyróżnić je „ze względu na ich formę: materialną (mogą nimi być pomniki, budynki, elementy przyrody ożywionej np. drzewa i nieożywionej) i niematerialną (to przede wszystkim wszelkiego rodzaju nazwy osób, zdarzeń oraz wytworów kultury)"

Zatem które miejsca materialne, związane z historią możemy nazwać miejscami pamięci? Z pewnością powinny to być miejsca w którymi wiążą się „nasze” wartości, idee, przeżycia. Określenie „nasze” oznaczać będzie w tym przypadku określoną grupę społeczną, która $\mathrm{z}$ otaczających ją miejsc zakorzenionych w przeszłości wybierze te, które są ważne dla niej „tu i teraz". Nie będzie to zatem zbiór przypadkowy, może to również nie być zbiór kompletny. Będzie on ukonstytuowany wskutek świadomego, subiektywnego wyboru.

5 Na podst. K. Kowalski, O istocie dziedzictwa europejskiego - rozważania, Kraków 2013, ss. 16-17.

6 Ibidem s. 19.

7 Ibidem s. 70.

8 Ibidem s. 57.

9 A. Szpociński, Nośniki pamięci, miejsca pamięci, [w:] Sensus Historiae, vol. XVII (2014/4), ss.18-19, www. sensushistoriae.epigram.eu/index.php/czasopismo/article/viewFile/230/233 dostęp [2018-02-15]. 


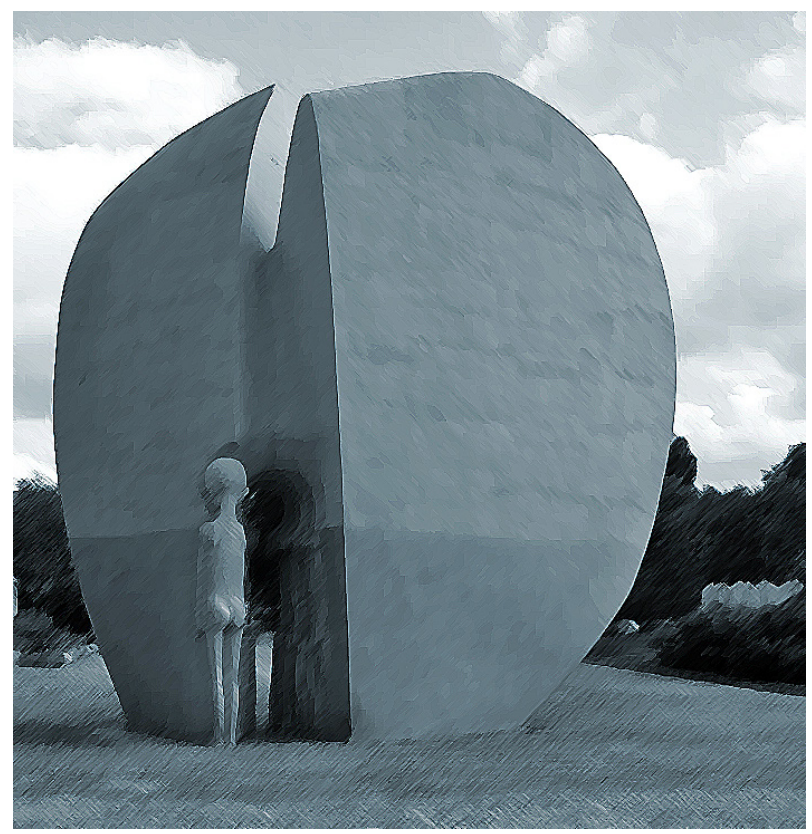

Ryc. 1 Pomnik Martyrologii i Pamięci Ofiar Dziecięcego Obozu Koncentracyjnego „Pęknięte Serce" w Parku im. Szarych Szeregów w Łodzi. Grafika wykonana na podst. zdjęcia https://lodz.ipn.gov.pl/dokumenty/zalaczniki/84/84-81323.jpg

Trudnym aspektem jest kwestia uzasadnienia utrzymywania i eksponowania miejsc ludzkiej tragedii oraz przemocy. Gregory Asworth stawia w tej kwestii pytanie „dlaczego mielibyśmy świadomie upamiętniać przemoc zadawaną ludziom przez innych ludzi i jej skutki - ludzkie cierpienie i traumę?"10 Dalej zwraca uwagę, że pamięć o przemocy może być bardzo silnym narzędziem używanym do różnych celów społecznych, politycznych czy ekonomicznych. Podstawowe aspekty to ideologiczne wzmocnienie społeczeństwa warunkujące wzmocnienie narodowych więzi. Jest to także moralne zobowiązanie do zachowania pamięci o tych, którzy stali się ofiarami przemocy i jednocześnie przestroga dla kolejnych pokoleń, aby nigdy więcej nie dopuścić do powtórzenia podobnej tragedii.

Oprócz miejsc przechowanych w pamięci społecznej, wyłaniają się także inne, odkryte w trakcie badań nad historią oraz przestrzenią, których pamięć należy dopiero przywrócić lub na nowo kształtować. Można w tym miejscu przywołać dwa przykłady 1) dziedzictwa archeologicznego, oraz 2) miejsc „porzuconych/ zapomnianych” np. dawnych, nieużytkownych cmentarzy. Przywołane przykłady to miejsca pozostające w uśpieniu i czekające na ich powtórne odkrycie w sensie dosłownym oraz metafizycznym. Miejsca porzucone przez ich wcześniejszych użytkowników, gdzie zerwana zostaje więź przeszłości i teraźniejszości, zjawisko, które można określić jako niepamięć miejsca. O niektórych takich miejscach, zachowują się mgliste przekazy (w różnej postaci), inne zostają pominięte i zapomniane celowo. Te pierwsze będą

10 G. Asworth, Planowanie dziedzictwa, Międzynarodowe Centrum Kultury, Kraków 2015, s. 269. 


\section{Miejsce pamiecci- pamięc miejsca, definiowanie i zasady ochrony [...]

usilnie poszukiwane, jak skarb, który należy odzyskać, te drugie być może zostaną odnalezione przypadkiem, w „lepszych czasach” gdy ich wartość na nowo zostanie odkryta i przywrócona. Niektóre miejsca zostaną zapomniane na zawsze. Zacieranie materialnych śladów pamięci, lub specjalne podnoszenie ich rangi dokonuje się z różnych powodów. Są to względy polityczne, ekonomiczne, czasem gospodarcze lub przestrzenne ${ }^{11} \mathrm{i}$ inne. Zatem pamięć o miejscu jest stale konfrontowana ze zmieniającymi się potrzebami współczesnych społeczeństw. Czy można zatem przyjąć obiektywne kryteria typowania i obiektywne zasady ochrony miejsc pamięci? Jak długo mają one szansę przetrwać w ciągle zmieniających się realiach współczesnego świata?

\section{Jak chronić miejsca pamięci w przestrzeni miasta, wsi, w krajobrazie}

Stopień i zakres ochrony miejsc pamięci zależy od ich „ciężaru gatunkowego” od treści i formy jaka tę niematerialną wartość i pamięć przenosi.

Najtrudniejsze i najbardziej przerażające w swojej wymowie są dawne miejsca zagłady, miejscach zbiorowych mordów, rozstrzeliwań, miejsca masowych mogił i pochówków, często zawierające szczątki ofiar bezimiennych lub trudnych do identyfikacji. Są to miejsca objęte szczególną ochroną, pamięcią zbiorową. Miejsca przeżyć traumatycznych i bolesnych również dla współczesnych pokoleń. Są one szczególnie ważne dla naszej narodowej, a nawet światowej pamięci, stąd do opieki nad nimi powołana została w 1947 r. Rada Ochrony Pomników i Męczeństwa (Rada OPiM) ${ }^{12}$, działająca od $1988 \mathrm{r}$. jako instytucja państwowa w postaci społecznego organu pod nazwą Rada Ochrony Pamięci Walk i Męczeństwa (Rada OPWiM) ${ }^{13}$, której zadania przejął w 2016 roku Instytut Pamięci Narodowej(IPN). W zakresie realizacji zadań polityki państwa oraz umów międzynarodowych dotyczących miejsc pamięci narodowej oraz grobów i cmentarzy wojennych odpowiedzialne jest Biuro Upamiętniania Walk i Męczeństwa (biuro działa przy centrali oraz jako komitety wojewódzkie przy oddziałach IPN) ${ }^{14}$.

Działająca do 2016 r. Rada OPWiM uznawała jako miejsca i pomniki pamięci narodowej „miejsca związane z upamiętnianiem historycznych wydarzeń i miejsc oraz postaci w dziejach walk i męczeństwa narodu polskiego w kraju i zagranicą, a także walk i męczeństwa innych narodów na terytorium Polski ${ }^{15}$. W tym czasie, w związku z toczącymi się pracami legislacyjnymi

$11 \mathrm{~Np}$. budowa nowych dróg i autostrad, usuwanie dawnych pomników i zastępowanie ich nowymi itp.

12 Ustawa z dnia 2 lipca 1947 r. o utworzeniu Rady Ochrony Pomników Męczeństwa (Dz.U. z 1947 r. Nr 52, poz. 264).

13 Ustawa z dnia 21 stycznia 1988 r. o Radzie Ochrony Pamięci Walk i Męczeństwa (Dz.U. 1988 nr 2 poz. 2).

$14 \mathrm{Na}$ podstawie https://ipn.gov.pl/pl/upamietnianie/38749,Upamietnianie-walk-i-meczenstwa.html, dostęp [2018-02-15]. Zasady, tryb powoływania, działania i finansowania Rady OPWiM określa Ustawa z dnia 21 stycznia 1988 r. o Radzie Ochrony Pamięci Walk i Męczeństwa (Dz. U. Nr 2, poz. 2, z późn. zm.) oraz Rozporządzenie Rady Ministrów z dnia 2 kwietnia 1988 r. w sprawie organizacji, trybu działania i zasad finansowania Rady Ochrony Pamięci Walk i Męczeństwa oraz komitetów ochrony pamięci walk i męczeństwa. (Dz. U. Nr 22, poz. 154).

15 Za Rada Ochrony Pamięci Walk i Męczeństwa, http://www.radaopwim.gov.pl/article_details/1/misja-rady/ dostęp [2014-09-04]. 
nad ustawą o miejscach pamięci narodowej pojawiła się propozycja definicji miejsc pamięci narodowej. Propozycję tę można traktować obecnie jako wykładnię z racji braku innych oficjalnych przepisów w tej kwestii. Określa ona, że miejscem pamięci narodowej jest: „1) upamiętnienie upamiętniające postaci lub wydarzenie, znaczące dla tożsamości i dziedzictwa Narodu i Państwa Polskiego lub innego narodu, w szczególności te związane z męczeństwem lub walką Polaków o niepodległość Rzeczypospolitej Polskiej, ustanowione miejscem pamięci narodowej w trybie przewidzianym niniejszą ustawą" lub Pomnik Zagłady ${ }^{16}$.

Jak widać na skrótowo zarysowanej problematyce formalno - prawnej, główny nacisk został położony na utrwalenie w pamięci Polaków miejsc pamięci o charakterze ogólnonarodowym, w szczególności związanych z upamiętnieniem „znaczących dla tożsamości i dziedzictwa Narodu i Państwa Polskiego wydarzeń, faktów i postaci”17. Do miejsc tych zaliczono przede wszystkim pomniki - byłe hitlerowskie obozy zagłady, cmentarze i mogiły wojenne, miejsca walk, obozów, łagrów, więzień oraz inne miejsca walki i męczeństwa.

Czy tak trudny i delikatny temat jak miejsca pamięci można poddać ścisłym, i bardzo jednoznacznym regulacjom prawnym? Na pewno ogólne ustalenia w tym zakresie są potrzebne, ale czy można nimi objąć tak trudne i zindywidualizowane dziedzictwo? Bo przecież każdy przypadek, każde miejsce, „lieu”, choć podobne, różni się swoją historią i specyfiką. W tym kontekście powraca wątek przekazu niematerialnego, jaki kryją w sobie konkretne miejsca, przestrzenie, krajobrazy. Zatem nie wystarczy miejscem pamięci określić tzw. nieruchomość gruntową, czy też wskazać obiekty budowlane lub pomnik, kluczem staje się pamięć miejsca. W taki właśnie sposób sprawę te naświetlał Pierre Nora, który zwracał uwagę na niematerialny aspekt „miejsc pamięci” rozumianych jako miejsca, gdzie „przechowywane” są wspomnienia ${ }^{18}$.

Takie pojmowanie miejsc pamięci otwiera ich szerokie spektrum rodzajowe, rożne kształty i formy. Otwiera także dyskusję nad innymi rodzajami miejsc pamięci, o charakterze bardziej lokalnym, nie regulowanym przepisami prawa polskiego. O tyle ważnymi, że „każda tożsamość zbiorowa jest jedynie zbliżona do wspólnego mianownika tożsamości indywidualnych" ${ }^{19}$.W tym zakresie odpowiedzialność za lokalne miejsca pamięci, za ich wskazanie, oraz propozycję ochrony (następnie jej sprawowanie) spoczywać powinna na organach terenowych w tym na Wojewódzkich Komitetach Ochrony Pamięci Walk i Męczeństwa oraz na samorządach gminnych (przy wsparciu merytorycznym i włączeniu do ochrony i opieki nad miejscami pamięci osób zainteresowanych tematem).

W gminach opieka i ochrona miejsc pamięci może być sprawowana przez powołanie

16 Projekt ustawy o miejscach pamięci, radalegislacyjna.gov.pl/sites/default/files/dokumenty/projekt_ ustawy_256.pdf, dostęp [2018-02-15]; Pomnik Zagłady, w rozumieniu art. 2 ustawy z dnia 7 maja 1999 r. o ochronie terenów byłych hitlerowskich obozów zagłady (Dz. U. Nr 41, poz. 412, z późn. zm.).

17 Projekt ustawy o miejscach pamięci, preambuła.

18 Poglądy Pierre’a Nora z artykułu „Memoire collective” przywołane za: A. Szpociński, Miejsca pamięci (lieux de memoire), www.staff.amu.edu.pl/ ewa/Szpocinski,\%20Miejsca\%20pamieci.pdf, dostęp [2018-02-15].

19 A. Tomaszewski, Ku nowej filozofii dziedzictwa, oprac. W. Święcicka, Międzynarodowe Centrum Kultury, Kraków 2012, s. 226. 


\section{Miejsce pamięci - pamięc miejsca, definiowanie i zasady ochrony [...]}

specjalnych wydziałówlub jednostek samorządu, lub też przez przypisanie zadań do jednostek już funkcjonujących. Np. w Łodzi zadania z tego zakresu przypisane zostały do Wydziału Gospodarki Komunalnej Urzędu Miasta Łodzi, który sprawuje opiekę nad właściwym utrzymaniem oraz czystością miejsc pamięci narodowej w Łodzi (przede wszystkim są to pomniki oraz tablice upamiętniające ${ }^{20}$. Część miejsc pamięci jest jednocześnie zabytkami, stąd zadania z zakresu ich ochrony spoczywają również na właściwych służbach konserwatorskich ${ }^{21}$.

Innym rodzajem udziału w ochronie miejsc pamięci są dokumenty planistyczne (ich rolę wskazano także w projekcie ustawy o miejscach pamięci). Obecnie wynika ona bezpośrednio $\mathrm{z}$ obowiązujących przepisów $\mathrm{z}$ zakresu planowania przestrzennego ${ }^{22}$. W planowaniu przestrzennym gminy uwzględnia się odpowiednio: w studium „obszary i zasady ochrony dziedzictwa kulturowego i zabytków oraz dóbr kultury współczesnej"23, w planie miejscowym: „zasady ochrony dziedzictwa kulturowego i zabytków, w tym krajobrazów kulturowych, oraz dóbr kultury współczesnej”24. Są to obowiązki i pojęcia na tyle obszerne i ogólne, że można przyjąć, iż mieści w sobie również miejsca pamięci rozumiane jako miejsca szczególne dla naszej zbiorowej pamięci, związane $\mathrm{z}$ historią miejsca, a zatem stanowiące dziedzictwo kultury. Oprócz tego ogólnego stwierdzenia, literalnie pojawia się obowiązek określenia w szczególności obszarów pomników zagłady i ich stref ochronnych wraz z wprowadzeniem obowiązujących na tych obszarach i strefach ograniczeń prowadzenia działalności gospodarczej (zgodnie z przepisami ustawy z dnia 7 maja 1999 r. o ochronie terenów byłych hitlerowskich obozów zagłady, Dz. U. z 2015 r. poz. 2120 ${ }^{25}$. Wyróżniając tę kategorię miejsc pamięci podkreślono ich rangę oraz ponadlokalne znaczenie dla zbiorowej pamięci narodowej, ale także globalnej światowej.

Dużą rolę w identyfikacji miejsc pamięci odrywają lokalne stowarzyszenia, koła naukowe, ale także nauczyciele szkół, a przede wszystkim starsi członkowie rodzin, którzy w kontakcie bezpośrednim przekazują wiedzę i pamięć. To w znacznej mierze od wielopłaszczyznowej edukacji zależeć będzie w przyszłości zrozumienie i ochrona, a zatem przetrwanie pamięci o miejscach wymagających upamiętnienia.

20 Na stronach wydziału zamieszczony został także wykaz miejsc pamięci narodowej w Łodzi. http://www. czystemiasto.uml.lodz.pl/pomniki_i_cmentarze.php?article_id=478 dostęp [2009-06-20].

21 Ustawa z dnia 23 lipca 2003 r. o ochronie zabytków i opiece nad zabytkami, Dz. U. z 2014 r. poz. 1446 z późn. $\mathrm{zm}$.

22 Ustawa z dnia 27 marca 2003 r. o planowaniu i zagospodarowaniu przestrzennym, Dz. U. z 2016 r. poz. 778 z późn. zm.

23 Art. 10, ust. 2, pkt. 4, Ustawa o planowaniu i zagospodarowaniu przestrzennym z dnia 27 marca 2003 r., Dz. U. z 2017 r. poz. $1073,1566$.

24 Ibidem, art. 15, ust. 2, pkt. 4., ale także zgodnie z pkt 7 ustala się obowiązkowo "granice $i$ sposoby zagospodarowania terenów lub obiektów podlegających ochronie, na podstawie odrębnych przepisów (...)”.

25 Ibidem, art. 10.ust.2, pkt 13. 


\section{Miejsca Pamięci w Łodzi - analiza dokumentów planistycznych}

Opracowywanie dokumentów strategicznych w skali miasta pociąga za sobą konieczność uwzględnienia wielu aspektów, wielu elementów zagospodarowania przestrzeni. Jednym z kluczowych zagadnień jest identyfikacja i ochrona dziedzictwa kulturowego oraz krajobrazu kulturowego, stanowiących materialny zapis tożsamości kulturowej społeczeństwa, będący nośnikiem przesłań historycznych, kulturalnych, patriotycznych ${ }^{26}$. Zachowanie tych wartości jest warunkiem ochrony dorobku kultury stworzonego „talentem i wysiłkiem wielu pokoleń naszych ojców”27. Na potrzeby nowo opracowywanych dokumentów polityki przestrzennej Łodzi, w ostatnich latach na nowo podjęto się rozpoznania miejsc pamięci. Zlokalizowane są one w rozproszeniu na całym obszarze miasta. Są to miejsca szczególne, usytuowane w śródmieściu, ale także ślady bitwy Łódzkiej, dawne, nieużytkowane i zapomniane cmentarze i inne. Szczególną kategorią są miejsca świadczące o dawnej obecności Żydów w Łodzi (miejsca gdzie stały synagogi, ich domy modlitwy, kuczki), ale także teren dawnego getta wyznaczonego przez niemieckiego okupanta czy stacja kolejowa Radegast, z której wywożono mieszkańców Łodzi i żydów do niemieckich obozów zagłady.

Jest również w Łodzi miejsce, którego historia jest szczególnie smutna, dotyczy bowiem najmłodszych - dzieci w wieku od 2 do 16 lat. W rejonie ulicy Przymysłowej i Brackiej, na terenie wydzielonym z getta żydowskiego władze okupacyjne założyły „Obóz prewencyjny (izolacyjny) dla młodych Polaków Policji Bezpieczeństwa w Łodzi (niem. Polen-Jugendverwahrlager der Sicherheitspolizei in Litzmannstadt)" ${ }^{\text {28 }}$. Obóz był z założenia miejscem pracy młodocianych więźniów, ale $\mathrm{z}$ uwagi na pracę ponad siły, bardzo złe warunki sanitarne, głodowe racje żywnościowe oraz brutalne traktowanie, surowe kary cielesne, choroby, część więźniów zmarła $^{29}$. Miejsce dawnego obozu oznaczone jest obecnie symbolicznym ogrodzeniem oraz upamiętnione pomnikiem „Pęknięte Serce” (Rycina 1).

Wymienione miejsca i obiekty pamięci narodowej, jak również wiele innych były do niedawna ewidencjonowane przez Wojewódzka Radę Ochrony Pamięci Walk i Męczeństwa $w Ł o d z i^{30}$. Obecnie pieczę nad badaniami i pogłębianiem wiedzy w tym zakresie sprawuje łódzki oddział IPN i działający przy nim Komitet OPWiM. Nadzór i opiekę nad miejscami pamięci narodowej sprawuje Wydział Gospodarki Komunalnej Urzędu Miasta Łodzi.

26 Na podst. A. Tomaszewski, Ku nowej filozofii dziedzictwa, oprac. Święcicka Ewa, Międzynarodowe Centrum Kultury, Kraków 2012, s. 226.

27 Ibidem.

28 https://pl.wikipedia.org/wiki/Ob\%C3\%B3z_przy_ulicy_Przemys\%C5\%82owej_w_\%C5\%81odzi [dostęp 2018-02-15].

29 Wg relacji pracującego ta lekarza tygodniowo umierało jedno, dwoje dzieci. Ibidem.

30 Obsługą Wojewódzkiej Rady Ochrony Pamięci Walk i Męczeństwa w Łodzi zajmował się Referat Dziedzictwa Kulturowego i Ochrony Pamięci Narodowej w Wydziale Polityki Społecznej Łódzkiego Urzędu Wojewódzkiego w Łodzi. 
Miejsce pamięci - pamięc miejsca, definiowanie i zasady ochrony [.... $\square \square^{55}$

\section{Studium}

Wiosnąbieżącego roku został uchwalony nowy dokument pt. „Studium uwarunkowań i kierunków zagospodarowania przestrzennego Łodzi” ${ }^{31}$. W dokumencie wyróżniono sześć podstawowych kategorii miejsc i pomników pamięci narodowej: 1) miejsca walk i martyrologii, 2) groby i mogiły wojenne, 3) pomniki i obeliski, 4) cmentarze (w tym cmentarze zapomniane), 5) wyburzone synagogi, 6) tablice pamiątkowe. (Rycina 2)

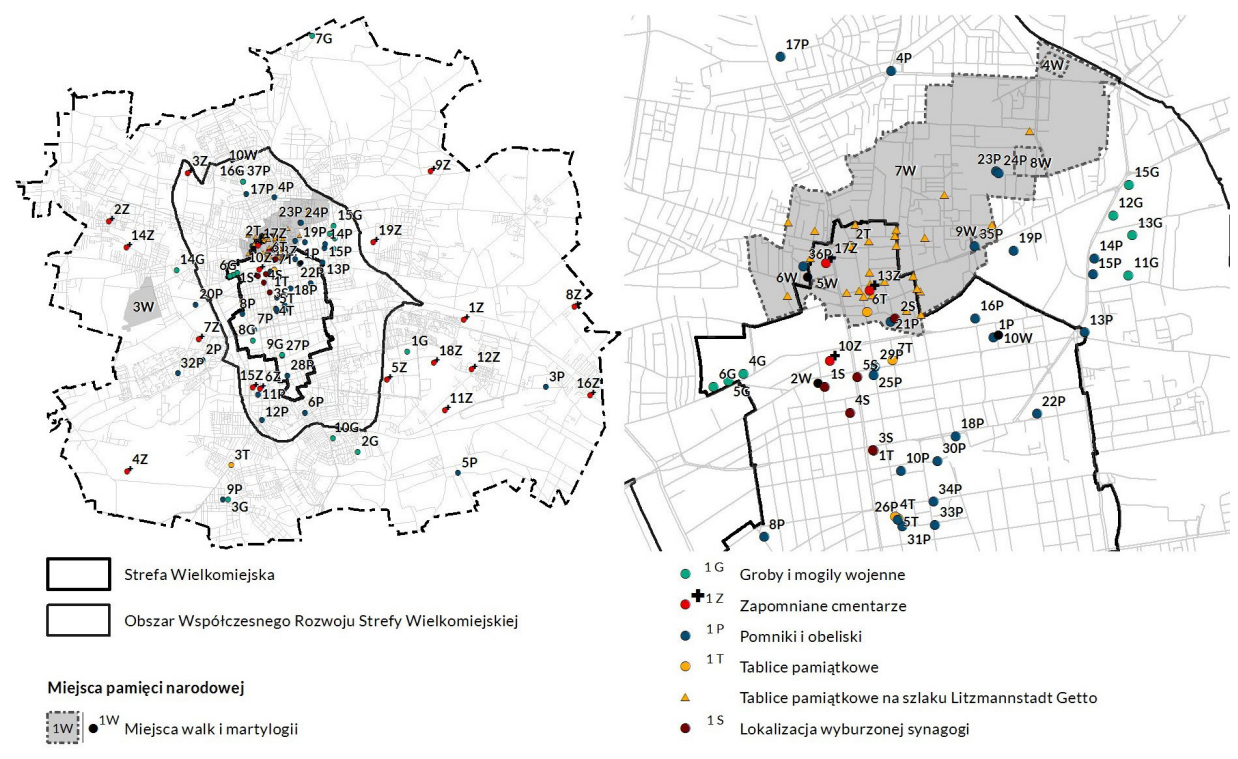

Ryc. 2 Schemat rozmieszczenia miejsc i pomników pamięci narodowej w Łodzi. Obszar oznaczony kolorem szarym (po prawo) wyznacza zasięg Litzmanstadt Getto. Rysunek wykonany w Miejskiej Pracowni Urbanistycznej w Łodzi, oprac. Miłosz Łukomski oraz Katarzyna Pielużek

Najbardziej znaczącymi obiektami w strukturze przestrzennej miasta, i jednocześnie najsilniej funkcjonującymi w świadomości mieszkańców, są:

1.miejsca walk i martyrologii:

- miejsca walk Bitwy Łódzkiej 1914 (na terenie Łodzi walki były prowadzone m.in. na terenach dzisiejszych Chojen, Zarzewa, Olechowa, Wiskitna),

- budynek Muzeum Tradycji Niepodległościowych przy ul. Gdańskiej 13 (dawne więzienie władz carskich, więzienie dla kobiet podczas okupacji hitlerowskiej, w latach 19451954 więzienie dla kobiet nadzorowane przez Urząd Bezpieczeństwa),

- mauzoleum na Radogoszczu - dwuelementowy zespół Muzeum Martyrologii i Walki

31 Uchwała nr LXIX/1753/18 Rady Miejskiej w Łodzi z dnia 28 marca 2018 r. w sprawie uchwalenia „Studium uwarunkowań i kierunków zagospodarowania przestrzennego miasta Łodzi”. 
(obejmuje dawne więzienie hitlerowskie, umieszczone w budynkach fabryki Abbego oraz Iglicę - pomnik ku czci zamordowanych więźniów),

- Stacja Radegast - pomnik-mauzoleum przy ul. Inflanckiej (miejsce deportacji Żydów do obozów zagłady),

- Obóz Koncentracyjny dla dzieci polskich (obóz przy ul. Przemysłowej),

- Obóz Romski (tereny przy ul. Wojska Polskiego),

- Litzmannstdt Getto (tereny dzisiejszych Bałut),

- budynek dawnej siedziby Gestapo i UB przy ul. Anstadta 7;

2. groby i mogiły wojenne:

- kwatery żołnierzy polskich z 1914 roku, dwie mogiły powstańców z 1863 roku Szymona Andrzejewskiego i Maksymiliana Kosińskiego - na cmentarzu katolickim p.w. św. Franciszka, ul. Rzgowska 156,

- grób Stanisława Linke, członka POW poległego w 1918 roku, na cmentarzu ewangelicko-augsburskim przy ul. Ogrodowej,

- groby żołnierzy radzieckich w Parku im. ks. Józefa Poniatowskiego;

3. pomniki i obeliski:

- Pomnik Martyrologii i Pamięci Ofiar Dziecięcego Obozu Koncentracyjnego „Pęknięte Serce" w Parku im. Szarych Szeregów na Bałutach,

- Pomnik Czynu Rewolucyjnego w Parku im. Marszałka Józefa Piłsudskiego przy ul. Konstantynowskiej,

- Pomnik Tadeusza Kościuszki przy Placu Wolności,

- Pomnik Nieznanego Żołnierza na Placu Katedralnym im. Jana Pawła II,

- Pomnik Ofiar Katynia przy ul. Łąkowej,

- Pomnik Chwały Żołnierzy Armii Łódź w Parku Helenów,

- Pomnik Marszałka Józefa Piłsudskiego na skwerze im. Związku Strzeleckiego;

4. cmentarze, $w$ tym cmentarze zapomniane:

Cmentarze są miejscami upamiętniającymi pamięć o zmarłych. Na ich terenie znajdują się często wydzielone miejsca pochówku żołnierzy oraz innych zasłużonych osób, np. poległych w obronie ojczyzny. Dwadzieścia trzy stare cmentarze łódzkie, zaliczane do kategorii miejsc pamięci narodowej, są jednocześnie uznane za zabytki poprzez wpis do rejestru zabytków lub gminnej ewidencji zabytków.

Oprócz cmentarzy czynnych na terenie miasta znajdują się również miejsca dawnych nekropolii pochodzących z XVII-XIX stulecia, które z czasem przestały pełnić swoją funkcję. $\mathrm{W}$ miejscu ich dawnej lokalizacji zachowały się niekiedy szczątkowe relikty, inne zniknęly 
Miejsce pamięci - pamięc miejsca, definiowanie i zasady ochrony [...] $\square \square^{57}$

z krajobrazu miasta ${ }^{32}$. Pierwszą grupę stanowią „zapomniane cmentarze” zlokalizowane na terenach dawnych wsi (obecnych przedmieść miasta), takich jak: Augustów, Grabieniec, Nowosolna, Żabieniec, Janów, Olechów, Retkinia. Drugą grupę stanowią cmentarze znajdujące się na terenie „starej” Łodzi:

- cmentarz na terenie Placu Kościelnego,

- cmentarz dwuwyznaniowy, znajdujący się dawniej między ulicami Ogrodową i Konstantynowską (dzisiejsza ul. Legionów),

- stary cmentarz żydowski na Bałutach, który był zlokalizowany przy dawnej ul. Wesołej ${ }^{33}$,

- nekropolia znajdująca się przy ul. Pięknej na Starym Rokiciu (obecnie Park im. T. Rejtana $)^{34}$.

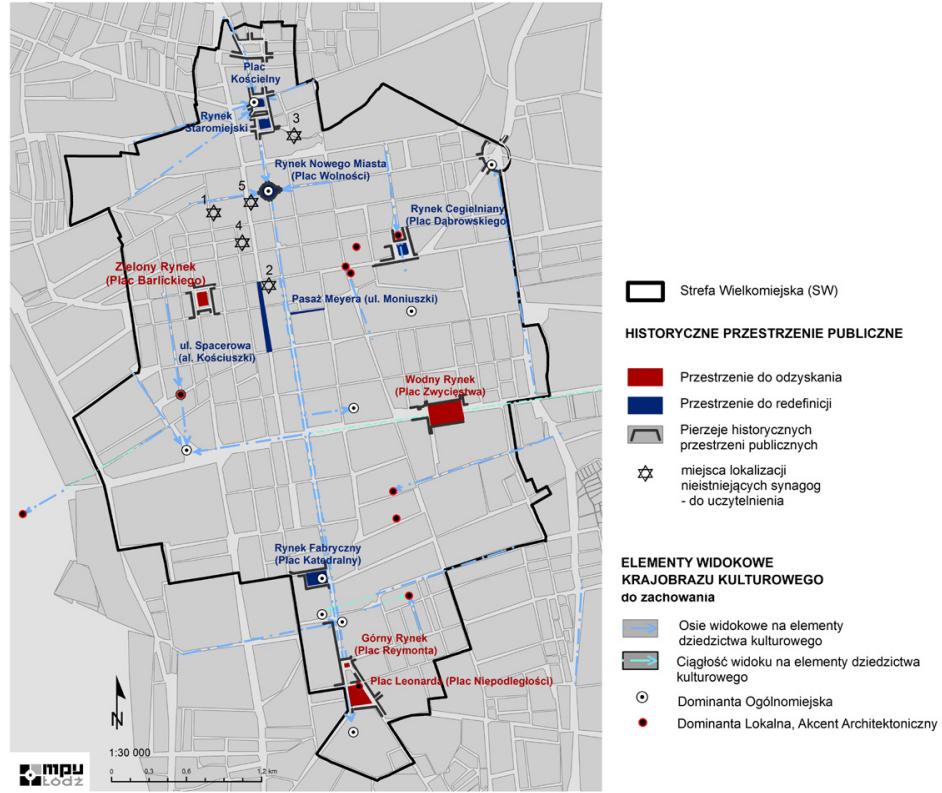

Ryc. $3 \mathrm{~W}$ przestrzeni miasta znajdują się często miejsca, krajobrazy warte utrwalenia, lub te których pamięć należy przywołać i ocalić. Są to np., miejsca synagog wyburzonych w czasie II wojny światowej, świadczące o wielokulturowości miasta. Rysunek wykonany w Miejskiej Pracowni Urbanistycznej w Łodzi, oprac. Miłosz Łukomski oraz Anna Lipińska

32 http://lodzhipsteremmiast.wordpress.com/2012/11/04/zapomniane-lodzkie-cmentarze2 [dostęp 2014-0903].

33 Po II wojnie światowej przez teren cmentarza wytyczono ul. Zachodnią, a po sąsiedzku wybudowano bloki mieszkalne. Pozostałością kirkutu są fragmenty ogrodzenia znajdujące się przy ulicach Bazarowej i Rybnej.

34 Dawny miejski cmentarz ewangelicki, który powstał w 1898 roku przy ul. Wiznera (zwany też cmentarzem Wiznera). Po sąsiedzku znajduje się niewielki, czynny cmentarzyk ewangelicko-reformowany, zlokalizowany przy ul. Rejtana (dawnej Huzarskiej), założony w 1904 roku. 
Obszar miasta, które w przeszłości stanowiły miejsca pochówku, to często miejsca pamięci cudzej, którą trzeba na nowo zinterpretować i zrehabilitować. Zasługują one na utrwalenie ich w krajobrazie, w pamięci i świadomości mieszkańców, w tym poprzez ich oznaczenie (uczytelnienie) $\mathrm{w}$ przestrzeni miasta oraz odpowiednie do przeszłości zagospodarowanie przestrzenne.

5. wyburzone synagogi:

Szczególne miejsca pamięci to te, gdzie wznosiły się dawniej synagogi, wyburzone podczas II wojny światowej przez okupanta niemieckiego (Ilustracja 2). Miejsca te wymagają upamiętnienia i uczytelnienia przestrzennego. Są to:

- ulica Gdańska 18, Mała Synagoga - Ohel Jakov,

- aleja Kościuszki 2, Synagoga Wielka - Reformowana,

- ulica Wolborska, Stara Synagoga - Altshtot,

- ulica Wólczańska 6, Synagoga Wołyńska - Ezras Izrael,

- ulica Zachodnia 56, Wilker Shul;

6. tablice pamiątkowe:

Tablice pamiątkowe są umieszczane w miejscach, mających związek np. $\mathrm{z}$ wydarzeniami historycznymi lub zasłużonymi postaciami. Znajdują się one na budynkach (np. tablica pamiątkowa twórcy kanalizacji w Łodzi - Stefana Skrzywana), na głazach (np. tablica pamiątkowa oddająca cześć żołnierzom Sztabu Armii Łódź oraz tablica poświęcona pamięci harcerek i harcerzy poległych w latach 1939-1945 - obie w Parku im. A. Mickiewicza na Julianowie), w posadzce ulic (np. tablice upamiętniające łódzkie getto i uczytelniające przebieg jego granic). Niektóre tablice wyznaczają szlak kulturowy lub/i szlak pamięci.

\section{Plany miejscowe - rekomendacje i refelksje}

Ogromne zróżnicowanie kategorii i lokalizacji miejsc pamięci na terenie miasta powoduje, że nie można przyjąć „a priori” jednego podobnego zapisu ochrony w planach miejscowych. Tym bardzie, że ustalenia dotyczące miejsc pamięci i ich stref ochronnych muszą uwzględniać nie tylko zasady ich ochrony, ale także wskazówki dopuszczalnych przekształceń, $\mathrm{w}$ tym zmiany sposobu użytkowania. Nawet tak wydawałoby się mało inwazyjne formy użytkowe jak lokalizacja parku na terenie dawnego cmentarza ewangelicko - augsburskiego w Łodzi przy ul. Pięknej, Rejtana, Felsztyńskiego i al. Politechniki wzbudzała do niedawna wiele kontrowersji. Obszar dawnego cmentarza, na którym zlokalizowano park im. Tadeusza Rejtana nie jest objęty planem miejscowym, a wprowadzenie nowej funkcji zostało uzasadnione potrzebami funkcjonalnymi. W opisywanym przykładzie, w zachodniej części terenu pozostawiono wydzielony, niewielki cmentarz ewangelicko-reformowany. W 1983 r., we wschodniej części dawnego cmentarza, na długiej, prostokątnej działce, urządzono park leśny. Działania realizacyjne zostały poprzedzone badaniami, ekshumacją szczątków pochowanych osób i przeniesieniem najcenniejszych nagrobków. Dużo wątpliwości wzbudziło wydzielenie na terenie parku placu zabaw dla dzieci, 


\section{Miejsce pamięci - pamięc miejsca, definiowanie i zasady ochrony $[. .$.

ale także niefrasobliwość właścicieli psów, którzy pozwalali swoim pupilom biegać swobodnie w miejscach dawnych pochówków. Jednak najbardziej oburzająca była niestaranność wykonawców parku i pozostawienie pomiędzy drzewami fragmentów dawnych nagrobków. Sytuacje poprawiła przebudowa parku, jaka miała miejsce w 2004 r., kiedy pozostawione $\mathrm{w}$ parku relikty nagrobków przeniesiono do lapidarium utworzonego obok zabytkowej bramy przy Felsztyńskiego ${ }^{35}$. Przedstawiony przykład pokazuje wieloaspektowość i złożoność problematyki. Jest to zarazem przykład miejsca „nie naszej pamięci”, które zostało na nowo zinterpretowane i zagospodarowane. W tym przypadku „cudza pamięć" miejsca nie została na nowo odkryta, została wyparta przez nowy sposób użytkowania.

Jakkolwiek nie byłoby pewnie możliwe i zasadne wprowadzanie jednolitych zasada ochrony miejsc pamięci, jednakże pewne ogóle wytyczne są możliwe a nawet konieczne do zdefiniowania. Wynikają one z istoty miejsc pamięci i służyć powinny ochronie nie tylko miejsca, jak również pamięci i jego „dobrego imienia”.

1. Pierwszą i podstawową rekomendacją jest, aby dla miejsc pamięci narodowej ustalić obligatoryjnie konieczność ochrony i sporządzenia lokalnego prawa np. w formie wpisu do rejestru zabytków, parku kulturowego lub ustaleń planu miejscowego.

2. Należy rozważyć ustanowienie stref ochrony ekspozycji lub otoczenia miejsca pamięci narodowej, których zasięg oraz zakres ustaleń zależeć powinien od rangi i specyfiki miejsca. (z uwzględnieniem zakazu lokalizacji elementów zagospodarowania, które mogłyby deprecjonować lub uwłaczać charakterowi i pamięci miejsca)

3. Należy jednoznacznie wydobyć, wskazać miejsca pamięci w krajobrazie kulturowym, poprzez ich odpowiednie oznakowania, uczytelnienie i zagospodarowanie.

4. Proponuje się, aby ustanowieniu strefy ochrony miejsc pamięci narodowej towarzyszyło tworzenie warunków rozwoju i restrukturyzacji obszaru - jego rewaloryzacji, rehabilitacji.

\section{Ochrona pamięci czy ochrona miejsca?}

Czy nie chroniąc miejsca można ochronić pamięć? Na ile trwała będzie wówczas pamięć? W dzisiejszym świecie, zdominowanym metodami wirtualnymi, odpowiedzi nie są jednoznaczne. Pojawiają się wirtualne lub rzeczywiste modele budynków (wirtualne synagogi łódzkie), pomników, a nawet fragmentów miast (np. projekt zaginiony kwartał w Łodzi). Pytanie jest o tyle ważne, że determinuje zasady postępowania w różnych przypadkach.

1. Miejsca, które bezwzględnie trzeba chronić, aby pamięć przetrwała i była wyrazista (przede wszystkim miejsca walki i męczeństwa);

35 Na podst. https://pl.wikipedia.org/wiki/Park_im._Tadeusza_Rejtana_w_\%C5\%81odzi [dostęp 2018-2-15] oraz przekazu ustnego babci. 
2. Miejsca, gdzie można dopuścić zmiany form przestrzennych oraz sposób użytkowania, ale koniecznie trzeba zachować informację (upamiętnić np. tablicą, pomnikiem, makietą, modelem wirtualnym)

3. Miejsca, gdzie trzeba pamięć zbiorową przywrócić, na nowo ukształtować (miejsca pamięci własnej lub cudzej, niezbędne są w tej mierze badania, edukacja, konkursy, dyskusje środowiskowe)

4. „Nowe miejsca pamięci”. Miejsca świadomego kreowania zbiorowej pamięci odwołujące się do tradycji, aktywności, wydarzeń, które minęły niedawno a mogą mieć znaczenie dla ciągłości tradycji miejsca i tożsamości społeczności ${ }^{36}$.

W uprzywilejowanej sytuacji znajdują się miejsca pamięci będące jednocześnie zabytkami. Ustawodawca w przepisach dotyczących ochrony zabytków wskazując zabytki nieruchome, które podlegają ochronie i opiece bez względu na stan zachowania wskazał, m.in. zabytki będące „miejscami upamiętniającymi wydarzenia historyczne bądź działalność wybitnych osobistości lub instytucji”"37. Ale również, nie określając że chodzi o zabytki, dopuszczono ochronę: nazw geograficznych, historycznych lub tradycyjnych nazw obiektu budowlanego, placu, ulicy lub jednostki osadniczej. Rozszerzono tym samym możliwość ochrony tzw. „pamięci miejsca” czyli jego tożsamości ${ }^{38}$.

Można postawić także przewrotnie inne pytanie: czy zabytki, w szczególności wpisane na listę rejestru, pomnika historii, światowego dziedzictwa UNESCO są miejscami pamięci? Są nośnikiem historii i związanych z nią wydarzeń osób (właścicieli, architektów i budowniczych). Są częścią składową krajobrazu kulturowego, który kształtuje naszą zbiorową tożsamość. Stanowiąc świadectwo minionej epoki, kultury budowlanej, być może wydarzenia, lub okresu historycznego itp. czy nie zasługują jednocześnie na przyporządkowanie im określenia „miejsce pamięci"? Za odrzuceniem takiej tezy stoją jednak wartości niematerialne, symbolika i przekaz historyczny jaki zawiera, lub nie zwiera w sobie zabytek. Dopiero połączenie miejsca i pamięci zapewnia komplementarność przekazu co do treści i formy.

\section{Wnioski i podsumowanie}

Niektóre miejsca w sposób szczególny przechowują naszą zbiorową pamięć, są materialnym nośnikiem naszej historii, kultury i tożsamości. Przechowują w materialnej postaci, w krajobrazie, historię i pamięć zarówno indywidualną jak i zbiorową. Zapewniają zachowanie więzi z przeszłością, spuścizną minionych pokoleń, dają poczucie wartości, dumy,

36 Czy dopuszczalne byłoby nowe spojrzenie na miejsca pamięci, rozszerzenie go również o miejsca, które w pewnym sensie są kreacją artystyczną choć jednocześnie odwołują się do przeszłości i tradycji miejsca jak np. rzeźby, postacie z bajek upamiętniające nie działający już łódzki SEMAFOR?

37 Art. 6, ust. 1., pkt. 1., Ustawa z dnia 23 lipca 2003 r. o ochronie zabytków i opiece nad zabytkami, Dz. U. 2017 poz. 2187.

38 Ibidem, art. 6 ust.2. 


\section{Miejsce pamięci - pamięc miejsca, definiowanie i zasady ochrony [...]}

zakorzenienia. Są to miejsca o różnej formie i różnej randze: światowej, europejskiej, narodowej, regionalnej ale także lokalnej. Miejsca pamięci są tematem trudnym, wielowątkowym, dotykającym często zagadnień delikatnych, takich jak ludzkie uczucia, pamięć, duma, są to również miejsca $\mathrm{z}$ którymi wiążą bolesne i smutne wspomnienia. Tym bardziej wskazać trzeba na potrzebę ogromnej pieczołowitości i staranności na każdym etapie ich rozpoznania, definiowania czy formułowania zasad ochrony lub dopuszczenia ewentualnego przekształcenia. Przekazanie pamięci miejsca poprzez zachowanie miejsc pamięci jest to ogromna zbiorowa odpowiedzialność i zarazem wyzwanie. 